\title{
UPTAKE ABILITY OF ZEOLITIC ROCK FROM SOUTH XEROVOUNI, AVDELLA, EVROS, HELLAS
}

\author{
Tzamos E. ${ }^{1}$, Filippidis A. ${ }^{1}$, Kantiranis N. ${ }^{1}$, Sikalidis C. ${ }^{2}$, Tsirambidis A. ${ }^{1}$, \\ Papastergios G. ${ }^{1}$, Vogiatzis D. ${ }^{3}$ \\ ${ }^{1}$ School of Geology, Dept. of Mineralogy-Petrology-Economic Geology, Aristotle University, 54124 \\ Thessaloniki,tzamos@geo.auth.gr,anestis@geo.auth.gr,kantira@geo.auth.gr,ananias@geo.auth.gr, \\ gpapaste@geo.auth.gr \\ ${ }^{2}$ Dept. of Chemical Engineering, Aristotle University, 54124 Thessaloniki, sikalidi@eng.auth.gr \\ ${ }^{3}$ School of Geology, Dept.of Geology, Aristotle University, 54124 Thessaloniki,dvogias@geo.auth.gr
}

\begin{abstract}
Zeolitic rock samples from South Xerovouni contain on average, 57 wt.\% HEU-type zeolite, 6 wt.\% clay minerals, $3 \mathrm{wt} . \%$ mica (total of $66 \mathrm{wt} . \%$ microporous minerals), $19 \mathrm{wt} . \%$ feldspars, $10 \mathrm{wt} . \%$ cristobalite and $5 \mathrm{wt} . \%$ quartz (total of $34 \mathrm{wt} . \%$ non-microporous minerals). Chemically the zeolitic rock consists mainly of $69.9 \mathrm{wt} . \% \mathrm{SiO}_{2}, 13.2 \mathrm{wt} . \% \mathrm{Al}_{2} \mathrm{O}_{3}, 1.2 \mathrm{wt} . \% \mathrm{Fe}_{2} \mathrm{O}_{3 \mathrm{t}}, 1.0 \mathrm{wt} . \% \mathrm{MgO}, 3.0 \mathrm{wt} . \%$ $\mathrm{CaO}, 1.5 \mathrm{wt} . \% \mathrm{Na}_{2} \mathrm{O}$ and $2.2 \mathrm{wt} . \% \mathrm{~K}_{2} \mathrm{O}$. The zeolitic rock shows an average ammonia ion exchange capacity of 150 meq/100g. HEU-type zeolite accounts for the most of the uptake ability, while clay minerals and mica contribute to a relative small extent only. The uptake ability of the five zeolitic rock samples showed positive correlations with the content of HEU-type zeolite as well as with the total content of microporous minerals (zeolite + mica + clay minerals). Such materials could be used in a wide range and scale of agricultural, aquacultural, and environmental applications.
\end{abstract}

Key words: zeolite, HEU-type, Xerovouni, CEC, mineralogy.

\section{Introduction}

Zeolites constitute a major class of crystalline hydrated aluminosilicate microporous minerals including both natural and synthetic species (Breck, 1974). The crystalline framework of the zeolites is based on a three dimensional network of $(\mathrm{Si}, \mathrm{Al}) \mathrm{O}_{4}$ tetrahedral and extra-framework alkali and alkaline-earth cations, which are loosely bound to the anionic charges within this framework structure and can be exchanged for other cations, including $\mathrm{H}^{+}$. High quality natural zeolites have many applications in industry, agriculture and the environment (e.g., Merkle and Slaughter, 1968; Barrer, 1978; Mumpton, 1978; Pond and Mumpton, 1984; Gottardi and Galli, 1985; Dyer, 1988; Tsitsishvili et al., 1992; Misaelides et al., 1993; Holmes, 1994; Ming and Mumpton, 1995; Misaelides et al., 1995a,b; Filippidis et al., 1996; Godelitsas et al., 1996a,b; Filippidis and Kassoli-Fournaraki, 2000; Bish and Ming, 2001; Kantiranis et al., 2002; Filippidis, 2008; Filippidis et al., 2008, 2009). The great majority of these applications employs their cation exchange capabilities and involves the replacement of the existing extra-framework cations with other cations from the surrounding environment. Due to the favourable ion-exchange selectivity of natural zeolites for certain cations, these minerals have been studied for potential use in the treatment of nuclear, municipal and industrial 
wastewaters and acid mine drainage waters. It is of economic importance that natural zeolites are used in their natural state so that expensive purification is avoided.

Zeolite-bearing rocks occur in a variety of geologic settings; mostly as alteration or authigenic minerals, low temperature-pressure minerals in metamorphic systems, secondary minerals in weathering zones or in vein-deposits. Commercially interesting zeolites are presently limited to authigenic and alteration settings in finely crystalline sedimentary rocks (Mumpton, 1978). Zeolites are widespread in Greece and clinoptilolite is the most common type (e.g., Tsolis-Katagas and Katagas, 1989, 1990; Stamatakis et al., 1996; Filippidis and Kassoli-Fournaraki, 2000; Kantiranis et al., 2002). Clinoptilolite is a high silica member of the heulandite group of natural zeolites and occurs in abundant and easily mined, sedimentary deposits in many parts of the world (Mumpton, 1988). The composition and purity of natural clinoptilolites and therefore their physicochemical properties vary widely between deposits and may even vary within the same deposit (Mercer and Ames Jr, 1978; Kassoli-Fournaraki et al., 2000).

The present study investigates the relationship between the mineralogy and the uptake ability of HEU-type zeolite-bearing tuffs from south Xerovouni, Avdella, Evros, Hellas.

\section{Geological setting}

The Metaxades upper Eocene zeolite-bearing volcanoclastic sediments belong to the Orestias Tertiary molassic basin of the northeastern Thrace in Greece. This meta-Alpine basin has an elongated shape and extends into Bulgaria. It is dominated by sediments of Eocene to Pleistocene age, deposited uncomfortably on the crystalline basement of the Rhodope massif. In the investigated area (Fig. 1) the formations recognized are (Koutles et al., 1995): Eocene formations consisting of: a) breccias-conglomerates (10-15 m thick), which lie uncomfortably upon the metamorphosed basement. Their composition is phyllitic, gneissic, amphibolitic, quartzitic or andesitic; they display a grading from coarser to finer fragments upwards, b) gray siltstones $(\sim 100 \mathrm{~m}$ thick) with psammitic and marly interlayers, c) mostly semi-loose sandstones (40-50 m thick) of varying grain-size, including very thin clayey interlayers, d) white to pale gray, yellow or green zeolite-bearing volcaniclastic tuffs (20-25 m of visible thickness) conformably deposited on the sandstones or siltstones; a thin layer of gray marl is discernible on the upper part of the tuffs, e) loose white-yellowish marly limestone (510 $\mathrm{m}$ thick) and $\mathrm{f}$ ) limestone (less than $30 \mathrm{~m}$ thick) rich in fossils. Oligocene formations of relatively great thickness, unconformable deposited on the Eocene formations. They consist of gray clays, red-yellowish sandstones, white-yellow siltstones and interlayers of marly limestone. Quaternary sediments of varying thickness, deposited over all previous formations. The complete sequence of the above formations is not always present in all sites of the basin. One or more formations may be locally absent due to tectonic activity, erosion or not deposition. In the broader area, two main visible faults and several fractures have been observed.

\section{Materials and Methods}

Five zeolitic tuff samples were taken from South Xerovouni of Avdella-Metaxades area (Fig. 1), in order to determine their mineralogical and chemical composition, petrographic characteristics, and uptake ability. The samples were studied in their bulk form, ground $(<125 \mu \mathrm{m})$ and homogenized. Samples for mineralogical and chemical analyses were ground further in an agate mortar, while thin sections were prepared for microscopic study. Chemical analyses of samples were carried out by AAS on a Perkin Elmer 5000 spectrometer equipped with a graphite furnace. 


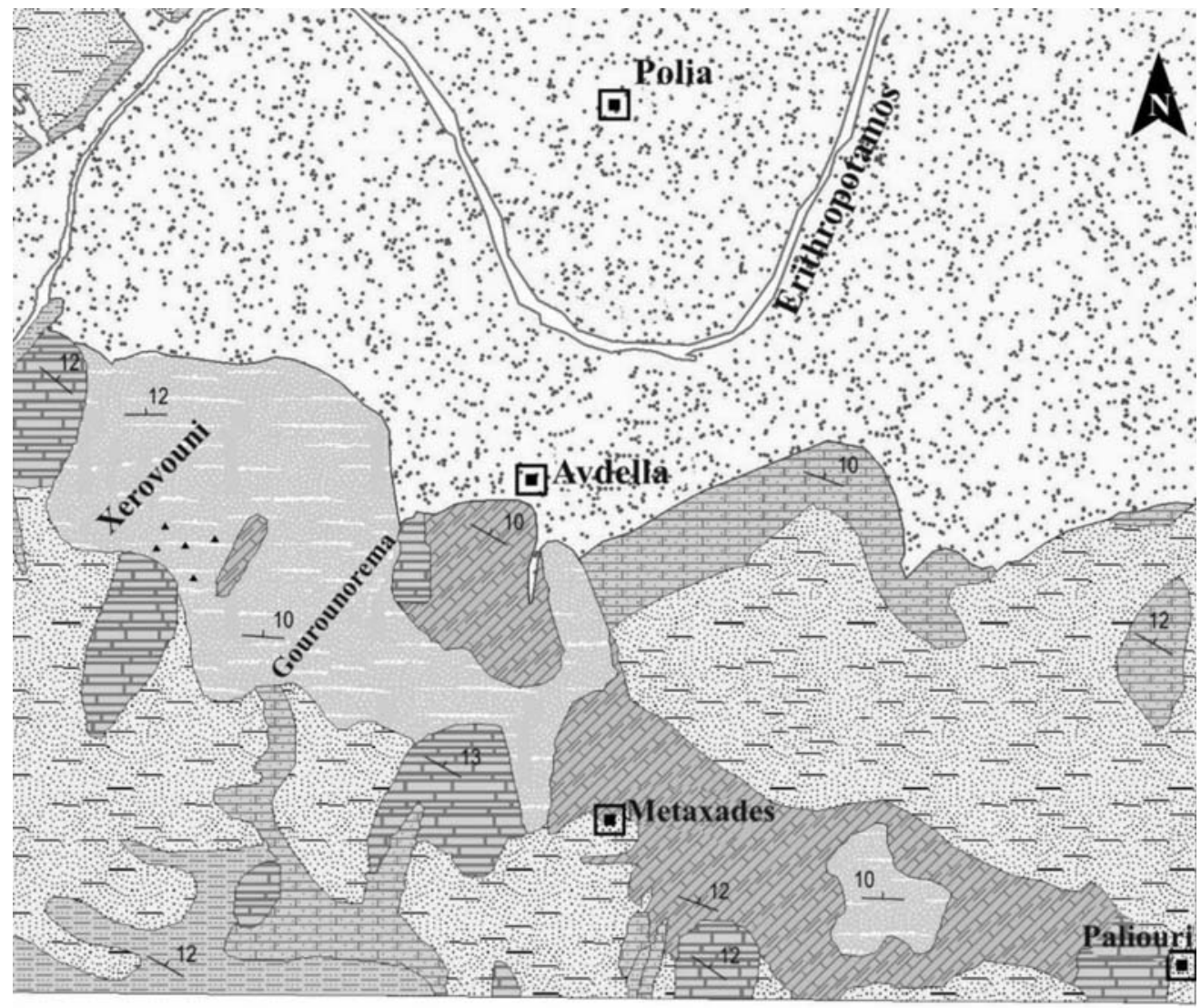

\section{LEGEND}

\begin{tabular}{|c|c|}
\hline & Holocene fluvio-terrestrial formations \\
\hline W. & Plio-Pleistocene formations \\
\hline 空空 & Limestones \\
\hline & Marly limestones \\
\hline & Volcaniclastic tuffs \\
\hline 要用 & Sandstones \\
\hline 풀퓨ㅍㅛㅛ표몀 & Siltstones \\
\hline$r^{15}$ & Strike and dip of beds \\
\hline$\Delta$ & Samples location \\
\hline 田 & Village \\
\hline
\end{tabular}

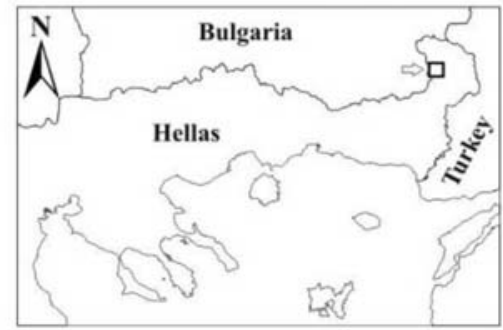

Fig. 1: Geological map and samples locations (modified, Koutles et al., 1995). 
The mineralogical composition of the samples was determined by X-ray Powder Diffraction (XRPD) method. The XRPD analysis was performed using a Philips PW1710 diffractometer with Ni-filtered $\mathrm{CuK}_{\alpha}$ radiation on randomly oriented samples. The counting statistics of the XRPD study were: step size: $0.01^{\circ} 2 \theta$, start angle: $3^{\circ}$, end angle: $63^{\circ}$ and scan speed: $0.02^{\circ} 2 \theta / \mathrm{sec}$. Quantitative estimates of the abundance of the mineral phases were derived from the XRPD data, using the intensity of certain reflections and external standard mixtures of minerals (Kantiranis et al., 2004).

In order to determine the sorption ability of each zeolite-rich sample, the samples were treated with $1 \mathrm{M}$ ammonium acetate $\left(\mathrm{NH}_{4} \mathrm{OAc}\right)$ aqueous solution, according to the AMAS method (Bain and Smith, 1987). Approximately $125 \mathrm{mg}$ of each $<125 \mu \mathrm{m}$ sample was added to a centrifuge tube with $10 \mathrm{~mL}$ of the $1 \mathrm{~N} \mathrm{NH}_{4} \mathrm{OAc}$ solution. The suspensions were well shaken, agitated for 24 hours, and then centrifuged. The clear liquid was discarded and the $\mathrm{NH}_{4} \mathrm{OAc}$-saturation procedure repeated 9 times, adding fresh $10 \mathrm{~mL}$ of $\mathrm{NH}_{4} \mathrm{OAc}$ solution each time. After the completion of the 10-day $\mathrm{NH}_{4} \mathrm{OAc}$-saturation, the excess $\mathrm{NH}_{4} \mathrm{OAc}$ was washed with $10 \mathrm{~mL}$ of $99 \%$ isopropyl alcohol, well shaken, and centrifuged. The clear supernatant liquid was discarded and the procedure repeated five times. The samples then were dried in room temperature. Following the $\mathrm{NH}_{4} \mathrm{OAc}$ saturation, the $\mathrm{NH}_{4}{ }^{+}$ions retained by the zeolite-rich samples, are converted using a strong base to $\mathrm{NH}_{3}$ and analysed by an ammonia electrode. The $\mathrm{NH}_{3}$ concentration was determined using an Orion potentiometric ammonia gas electrode combined with a Jenway $3045 \mathrm{pH} / \mathrm{mV} /$ ion analyser. Each air-dried $\mathrm{NH}_{4}{ }^{+}$-saturated sample was placed in a $100 \mathrm{~mL}$ Pyrex beaker containing a Teflon covered stirring bar. Deionised nitrogen-free water $(50 \mathrm{~mL})$ was added and the solution was stirred to suspend the sample. The electrode was immersed into the suspension taking care to prevent entrapment of air under the concave tip. By addition of $0.5 \mathrm{~mL}$ of $10 \mathrm{M} \mathrm{NaOH}$, the $\mathrm{NH}_{3}$ measurements were taken at constant level achievement. The electrode calibration was performed daily using ammonium calibrating solutions of 10, 100 and $1000 \mathrm{ppm}$ provided by Jenway and hourly using the $10 \mathrm{ppm}$ ammonium solution.

\section{Results and Discussion}

The study of the thin sections show the presence of zeolite, mica (biotite), clay minerals (mainly smectite), feldspars, quartz and amorphous material (Fig. 2). Also, were recognized glass shards, i.e. sites of altered volcanic glass, which consist from outer to inner of clay minerals and fine zeolite crystals (Fig. 3).

The semi-quantitative mineralogical composition (wt. \%), the total micro-porous mineral content (wt. $\%$ ) and the uptake ability of all samples are presented in Table 1. The major mineral phase present in the studied samples is found to be HEU-type zeolite, with percentages varying from $42 \mathrm{wt} . \%$ (sample X1) to $67 \mathrm{wt} . \%$ (sample X4), with an average amount of $57 \mathrm{wt} . \%$. These results are in good agreement with previous studies on the zeolitic tuffs of Metaxades Area, which report an average amount of 58 wt.\% in HEU-type zeolite (Marantos et al., 1989; Tsirambides et al., 1989, 1993; Tsirambides, 1991; Filippidis, 1993; Misaelides et al., 1994a,b, 1995a,b; Koutles et al., 1995; Symeopoulos et al., 1996; Haidouti, 1997; Tserveni-Gousi et al., 1997; Sikalidis, 1998; Yannakopoulos et al., 1998; Vlessidis et al., 2001; Filippidis and Kassoli-Fournaraki, 2002; Katranas et al., 2003; Papadopoulos et al., 2004; Filippidis and Kantiranis, 2005; Kantiranis et al., 2006; Filippidis et al., 2007). In minor amounts plagioclase (5-21 wt.\%), K-feldspar (4-19 wt.\%), cristobalite (3-17 wt.\%), quartz (3-8 wt.\%), micas (3-4 wt.\%) and clay minerals (4-11 wt.\%), were also determined. The total percent of micro-porous minerals (zeolite + micas + clays minerals) vary from 49 wt.\% (sample $\mathrm{X} 1$ ) to $75 \mathrm{wt} . \%$ (sample X4), while feldspars + quartz + crystobalite constitute the non-microporous content of the samples varying between $25 \mathrm{wt} . \%$ (sample X4) and $51 \mathrm{wt} . \%$ (sample X1). 


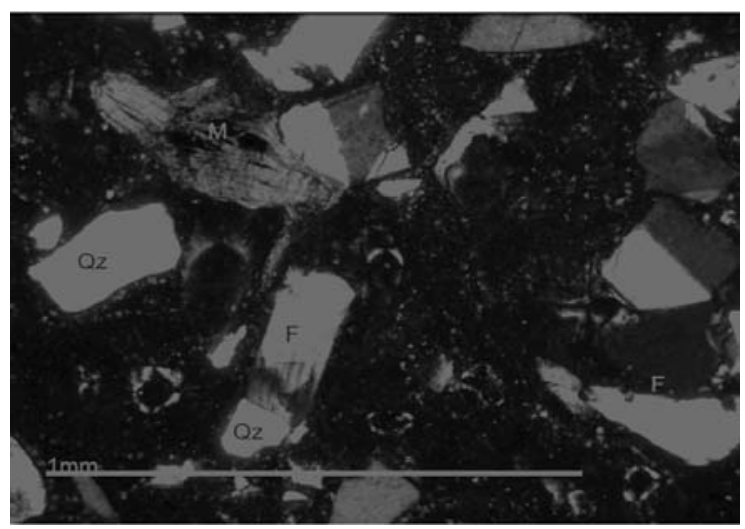

Fig. 2: Representative microphotograph of the studied samples. Qz=Quartz, M=Mica (biotite), F=Feldspars (Nicols + ).

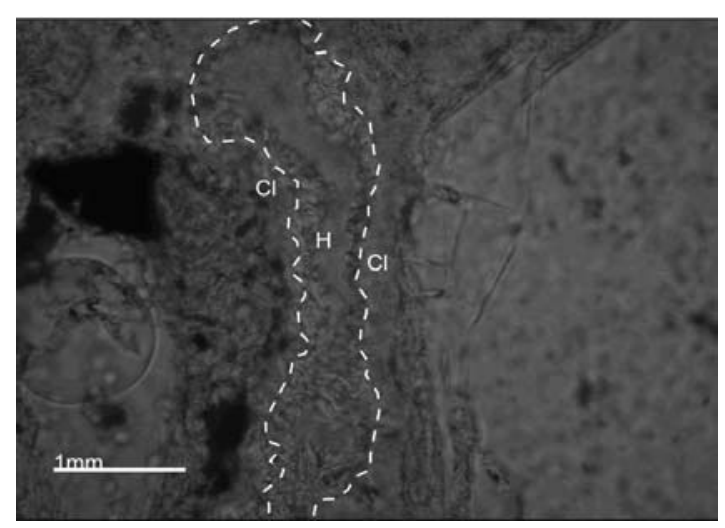

Fig. 3: A glass shard (white line). H=HEU-type zeolite, $\mathrm{Cl}=$ Clay minerals (Nicols //).

The chemical compositions of the zeolite-bearing rock samples are presented in Table 2. All samples contain high amounts of $\mathrm{SiO}_{2}$ varying between $69.24 \mathrm{wt}$. \% (sample X1) and $70.63 \mathrm{wt} . \%$ (sample X4). The $\mathrm{Al}_{2} \mathrm{O}_{3}$ content measured from 12.12 wt. \% (sample X4) to $14.57 \mathrm{wt}$. \% (sample X1). Low amounts of $\mathrm{TiO}_{2}, \mathrm{MnO}$ and $\mathrm{Fe}_{2} \mathrm{O}_{3 \mathrm{~T}}$ were also found. The total percentage of oxides of the exchangeable cations $\mathrm{Mg}, \mathrm{Ca}, \mathrm{Na}$, and K vary between 6.84 wt. \% (sample X4) and 9.11 (sa-mple X1) with a mean value of $7.75 \mathrm{wt} . \%$. These cations mainly came from the zeolite framework, but also high amounts of feldspars and /or micas + clays may affect their content, especially in sample X1. Loss of ignition varies between 6.07 wt.\% (sample X1) and 9.42 wt.\% (sample X4).

The chemical formula of the HEU-type zeolite in the studied area, calculated from microprobe analyses of prior studies (Tsirambides et al., 1993; Koutles et al., 1995; Kantiranis et al., 2006) is $\mathrm{Ca}_{2.1} \mathrm{~K}_{0.5} \mathrm{Mg}_{0.3} \mathrm{Na}_{0.3} \mathrm{Al}_{6.3} \mathrm{Si}_{29.9} \mathrm{O}_{72} \cdot 18.9 \mathrm{H}_{2} \mathrm{O}$.

The measured uptake ability varies between $111 \mathrm{meq} / 100 \mathrm{~g}$ (sample X1) and $176 \mathrm{meq} / 100 \mathrm{~g}$ (sample X4), with an average value of $150 \mathrm{meq} / 100 \mathrm{~g}$ for all five samples (Table 1). This value is in very good agreement with the theoretical value of $152 \mathrm{meq} / 100 \mathrm{~g}$ calculated taking in considerations the mineralogical composition of the samples and the theoretical ion exchange capacity values of clinop- 
Table 1. Semi-quantitative mineralogical composition (wt.\%) and uptake ability (meq/100g) of the South Xerovouni samples.

\begin{tabular}{|l|c|c|c|c|c|c|}
\hline Sample & X1 & $\mathbf{X 2}$ & $\mathbf{X 3}$ & $\mathbf{X 4}$ & $\mathbf{X 5}$ & Average \\
\hline HEU-type zeolite & 42 & 62 & 52 & 67 & 59 & 57 \\
\hline Micas (Biotite) & 3 & 3 & 4 & 3 & 4 & 3 \\
\hline Clay Minerals & 4 & 6 & 11 & 5 & 5 & 6 \\
\hline K-Feldspars & 19 & 8 & 9 & 6 & 4 & 9 \\
\hline Plagioclases & 21 & 8 & 9 & 6 & 5 & 10 \\
\hline Quartz & 8 & 3 & 4 & 3 & 6 & 5 \\
\hline Cristobalite & 3 & 10 & 11 & 10 & 17 & 10 \\
\hline Micro-porous minerals & 49 & 71 & 67 & 75 & 68 & 66 \\
\hline Uptake ability & 111 & 164 & 143 & 176 & 156 & 150 \\
\hline
\end{tabular}

Table 2. Whole rock chemical analyses (wt.\%) of South Xerovouni samples.

\begin{tabular}{|l|c|c|c|c|}
\hline Sample & $\mathbf{X 1}$ & $\mathbf{X 3}$ & $\mathbf{X 4}$ & Average \\
\hline $\mathrm{SiO}_{2}$ & 69.24 & 69.91 & 70.63 & 69.93 \\
\hline $\mathrm{TiO}_{2}$ & 0.08 & 0.10 & 0.07 & 0.08 \\
\hline $\mathrm{Al}_{2} \mathrm{O}_{3}$ & 14.57 & 12.81 & 12.12 & 13.17 \\
\hline $\mathrm{Fe}_{2} \mathrm{O}_{3} \mathrm{t}$ & 1.25 & 1.30 & 0.92 & 1.16 \\
\hline $\mathrm{MnO}$ & 0.09 & 0.09 & 0.11 & 0.10 \\
\hline $\mathrm{MgO}$ & 0.89 & 1.22 & 0.92 & 1.01 \\
\hline $\mathrm{CaO}$ & 2.75 & 2.89 & 3.33 & 2.99 \\
\hline $\mathrm{Na} \mathrm{O}_{2} \mathrm{O}$ & 2.47 & 1.21 & 0.90 & 1.53 \\
\hline $\mathrm{K} 2 \mathrm{O}$ & 3.00 & 1.98 & 1.69 & 2.22 \\
\hline L.O.I.* & 6.07 & 8.63 & 9.42 & 8.04 \\
\hline Total & 100.41 & 100.13 & 100.10 & 100.23 \\
\hline
\end{tabular}

*LOI=Loss of Ignition

tilolite (254 meq/100g, Mumpton, 1977), smectite (100 meq/100g, Deer et al., 1992) and biotite (25 meq/100g, Deer et al., 1992).

The comparison between the mineralogical composition and the uptake ability, results in positive correlation between the uptake ability and the wt.\% composition in zeolite and total micro-porous minerals. The correlation coefficients were found 0.99 and 0.95 respectively (Figs 4 and 5). 


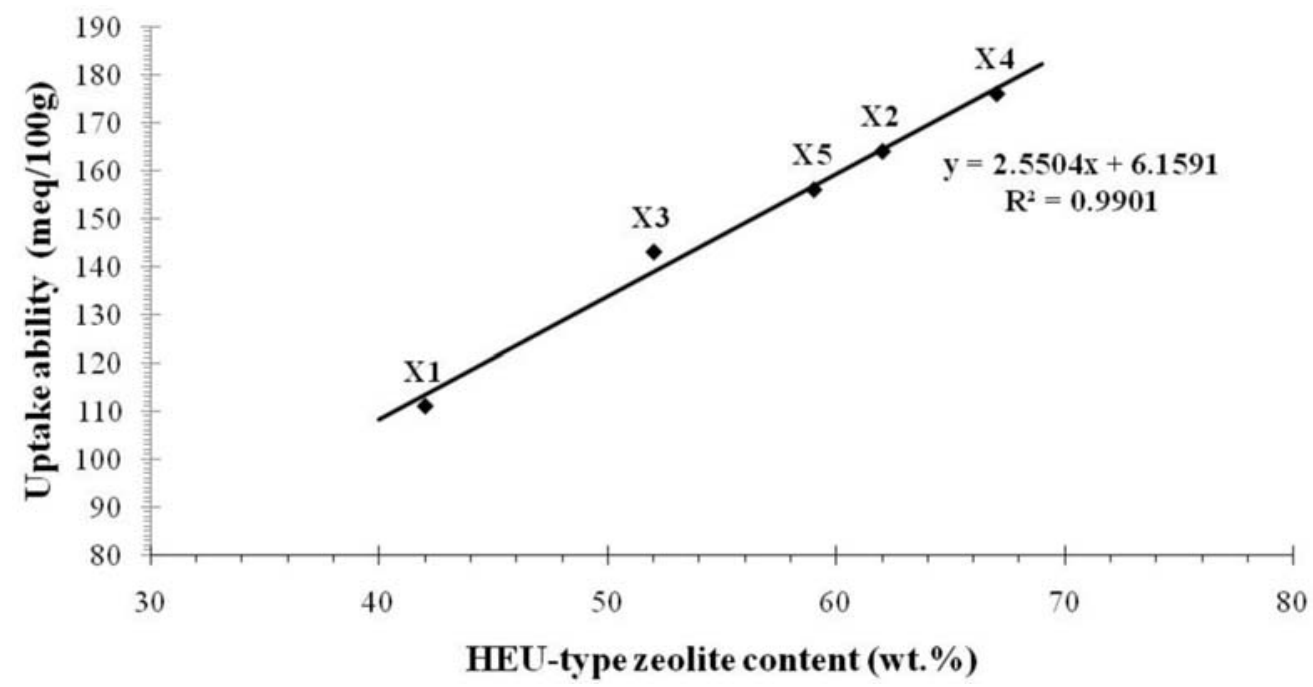

Fig. 4: Correlation of HEU-type zeolite content $v s$ uptake ability of South Xerovouni samples.

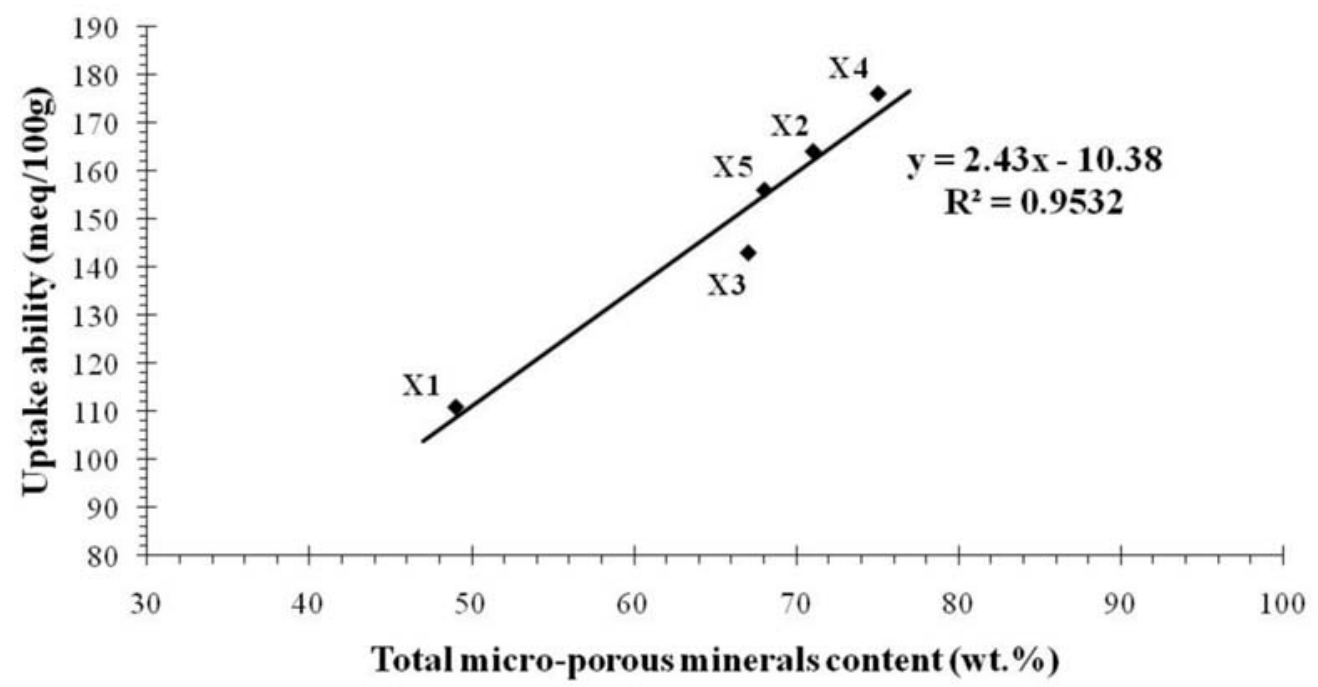

Fig. 5: Correlation of total micro-porous minerals content $v s$ uptake ability of South Xerovouni samples.

The measured uptake abilities gives the opportunity of utilizing the studied South Xerovouni zeolitic tuffs in a wide range of environmental applications, such as: improvement of drinking water, purification of municipal and industrial wastewaters and wastewater treatment units, conversion of sewage sludge and manure to odourless fertilizer, oxygen enrichment of aqua, fishery and fish breeding for production of healthier food, soil amendment, odour control and gas purification and drying systems. 


\section{Conclusions}

Five zeolitic tuff samples were taken from South Xerovouni of Avdella-Metaxades area, in order to determine their mineralogical and chemical composition, petrographic characteristics, and uptake ability. The major mineral phase present in the studied samples is found to be HEU-type zeolite, with an average amount of $57 \mathrm{wt} \%$. In minor amounts plagioclase, K-feldspar, cristobalite, quartz, micas and clay minerals, were also determined. The total percent of micro-porous minerals (zeolite + micas + clay minerals) vary from 49 to $75 \mathrm{wt} . \%$, while the non-microporous content between 25 and $51 \mathrm{wt} . \%$. All samples contain high amounts of $\mathrm{SiO}_{2}$ varying between 69.24 and $70.63 \mathrm{wt}$. \%. The $\mathrm{Al}_{2} \mathrm{O}_{3}$ content measured from 12.12 to 14.57 wt. \%, while low amounts of $\mathrm{TiO}_{2}, \mathrm{MnO}$ and $\mathrm{Fe}_{2} \mathrm{O}_{3 \mathrm{~T}}$ were also found. The total percentage of oxides of the exchangeable cations $\mathrm{Mg}, \mathrm{Ca}, \mathrm{Na}$, and $\mathrm{K}$ vary between 6.84 and $9.11 \mathrm{wt} . \%$ with a mean value of $7.75 \mathrm{wt} . \%$. These cations mainly came from the zeolite framework, but also high amounts of feldspars and /or micas + clays may affect their content. Loss on ignition vary between 6.07 and $9.42 \mathrm{wt} . \%$. The measured uptake ability varies between 111 and $176 \mathrm{meq} / 100 \mathrm{~g}$, with an average value of $150 \mathrm{meq} / 100 \mathrm{~g}$ for all five samples, showing a positive correlation with the zeolite and total micro-porous minerals content.

\section{References}

Bain, C. \& Smith, L., 1987. Chemical analysis. In: Wilson M. (ed.), A handbook of determinative methods in clay mineralogy, Glasgow, Blackie, 248-274.

Barrer, R.M., 1978. Zeolite and Clay Minerals as Sorbents and Molecular Sieves, New York, Academic Press, 499pp.

Bish, D.L. \& Ming, D.W., 2001. Natural Zeolites: Occurrence, Properties, Applications. Mineralogical Society of America , Reviews in Mineralogy and Geochemistry, vol. 45, Washington DC, 654 p.

Breck, D.W., 1974. Zeolite Molecular Sieves, Structure, Chemistry and Use, New York, J. Wiley, 771pp.

Deer, W.A., Howie, R.A. \& Zussman, J., 1992. An Introduction to the Rock-Forming Minerals, 2nd edn. London, Longman, 696pp.

Dyer, A., 1988. An Introduction to Zeolite Molecular Sieves, Chichester, J. Wiley, 149pp.

Filippidis, A. 1993. New find of moissanite in the Metaxades zeolite-bearing volcaniclastic rocks, Thrace County, Greece. Neues Jahrbuch fur Mineralogie Monatshefte, 11, 521-527.

Filippidis, A. 2008. Treatment and recycling of municipal and industrial waste waters using Hellenic Natural Zeolite: A Review. AQUA 2008, $3^{\text {rd }}$ Intern. Conf. Water Science and Technology (Athens, 1619/10), CD-Proceedings, 5p.

Filippidis, A. \& Kantiranis, N., 2005. Industrial, agricultural and environmental uses of the natural zeolites of Thrace. Proc. Sci. Meet. of G.S.G. (Samothraki, 2-4/9), Bull. Geol. Soc. Greece, 37, 90-101 (in Greek with English summary).

Filippidis, A. \& Kassoli-Fournaraki, A., 2002. Management of aquatic ecosystems using Greek natural zeolites. $12^{\text {th }}$ Sem. Environmental Protection (Thessaloniki, 2-5/12), Proceedings, 75-82 (in Greek).

Filippidis, A.\& Kassoli-Fournaraki, A., 2000. Environmental uses of natural zeolites from Evros district, Thrace, Greece. In: Anagnostopoulos A. (Ed.), Proc. 5th Int. Conf. on Environ. Pollution. 149-155, Thessaloniki, G. Korakidis Press, 1026pp.

Filippidis, A., Godelitsas, A., Charistos, D., Misaelides, P. \& Kassoli-Fournaraki, A., 1996. The chemical behavior of natural zeolites in aqueous environments; interaction between low-silica zeolites and $1 \mathrm{M} \mathrm{NaCl}$ solutions of different pH-values, Applied Clay Science 11, 199-209.

Filippidis, A., Kantiranis, N., Stamatakis, M., Drakoulis, A. \& Tzamos, E., 2007. The cation exchange capacity of the Greek zeolitic rocks. Bull. Geol. Soc. Greece, 40(2), 723-735. 
Filippidis, A., Apostolidis, N., Paragios, I. and Filippidis, S. 2008. Zeolites clean up. Industrial Minerals, April, 68-71.

Filippidis, A., Papastergios, G., Apostolidis, N., Paragios, I., Filippidis, S. and Sikalidis, C. 2009. Oderless and cohesive zeo-sewage sludge produced by Hellenic Natural Zeolite treatment. $3^{\text {rd }}$ AMIREG Intern. Conf. Assessing the Footprint of Resource Utilization and Hazardous Waste Management (Athens, 7-9/9), Proceedings, 96-100.

Godelitsas, A., Misaelides, P., Charistos, D., Filippidis, A. \& Anousis, I., 1996a. Interaction of HEU-type zeolite crystals with Thorium aqueous solutions. Chem. Erde 56, 143-156.

Godelitsas, A., Misaelides, P., Filippidis, A., Charistos, D. \& Anousis, I., 1996b. Uranium sorption from aqueous solutions on sodium-form of HEU-type zeolite crystals. J. Radioan . Nucl. Ch. Ar. 208, 393-402.

Gottardi, G. \& Galli, E., 1985. Natural zeolites, Berlin, Springer, 409pp.

Haidouti, C., 1997. Inactivation of mercury in contaminated soils using natural zeolites. The Science of the Total Environment, 208, 105-109.

Holmes, D.A., 1994. Zeolites. In: Industrial Minerals and Rocks (D.D. Carr, ed.), Braun-Brumfield, Michigan, 1129-1158.

Kantiranis, N., Chrissafis, C., Filippidis, A. \& Paraskevopoulos, K., 2006. Thermal distinction of HEUtype mineral phases contained in Greek zeolite-rich volcaniclastic tuffs. European Journal of Mineralogy, 18(4), 509-516.

Kantiranis, N., Stamatakis, M., Filippidis, A. \& Squires, C. 2004. The uptake ability of the clinoptilolitic tuffs of Samos Island, Greece. Bull. Geol. Soc. Greece, 36(1), 89-96.

Kantiranis, N., Filippidis, A., Mouhtaris, Th., Charistos, D., Kassoli-Fournaraki, A. \& Tsirambides, A., 2002. The uptake ability of the Greek natural zeolites, ZEOLITE '02, 6th Int. Conf. on the Occurrence, Properties and Utilization of Natural Zeolites, Thessaloniki (June, 3-7 2002), 155-156.

Kassoli-Fournaraki, A., Stamatakis, M., Hall, A., Filippidis, A., Michailidis, K., Tsirambides, A. \& Koutles, Th., 2000. The Ca-rich clinoptilolite deposit of Pentalofos, Thrace, Greece. In: Collela C. \& Mumpton F.A. (Eds.), Natural Zeolites for the Third Millennium, Napoli, De Frede Editore, 193-202.

Katranas, T.K., Vlessidis, A.G., Tsiatouras, V.A., Triantafyllidis, K.S. \& Evmiridis, N.P., 2003. Dehydrogenation of propane over natural clinoptilolite zeolites. Microporous and Mesoporous Materials, 61, 189-198.

Koutles, Th., Kassoli-Fournaraki, A., Filippidis, A. \& Tsirambides, A. 1995. Geology and geochemistry of the Eocene zeolitic-bearing volcaniclastic sediments of Metaxades, Thrace, Greece. Estudios Geologicos, 51, 19-27.

Marantos, I., Koshiaris, G., Karantasi, S. \& Gregoriadis, G., 1989. A study on zeolitic alteration of Tertiary pyroclastics from Metaxades area, Evros County, Greece. Bull. Geol. Soc. Greece, 23(2), 443 450 (in Greek with English abstract).

Mercer, B.W. \& Ames, Jr.L.L., 1978. Zeolite Ion Exchange in Radioactive and Municipal Watewater treatment. In: Sand L.B. \& Mumpton F.A. (Eds.), Natural Zeolites, Occurrence, Properties, Uses, Oxford, Pergamon Press, 451-459.

Merkle, A.B. \& Slaughter, M., 1968. Determination and refinement of the structure of heulandite. American Mineralogist 53, 1120-1138.

Ming, D.W. \& Mumpton, F.A., 1995. Natural zeolites '93: Occurrence, Properties, Use, International Committee on Natural zeolites, New York, Brockport, 622pp.

Misailidis, P., Godelitsas, A. \& Filippidis A., 1994a. Cesium uptake by zeoliferous rocks from Metaxades, Thrace, Greece. $15^{\text {th }}$ Pan-Hellenic Chemistry Congress, Thessaloniki, Proc. A, 218-221 (in Greek with English summary). 
Misaelides, P., Godelitsas, A. \& Filippidis A. 1995a. The use of zeoliferous rocks from Metaxades-Thrace, Greece, for the removal of caesium from aqueous solutions. Fresenius Environmental Bulletin, 4, 227-231.

Misaelides, P., Godelitsas, A., Charistos, V., Ioannou, D. \& Charistos, D., 1994b. Heavy metal uptake by zeoliferous rocks from Metaxades, Thrace, Greece: An exploratory study. Journal of Radioanalytical and Nuclear Chemistry, Articles, 183, 159-166.

Misaelides, P., Godelitsas, A., Filippidis, A., Charistos, D. \& Anousis, I.. 1995b. Thorium and uranium uptake by natural zeolitic materials. The Science of the Total Environment, 173/174, 237-246.

Misaelides, P., Godelitsas, A., Haristos, D., Noli, F., Filippidis, A. \& Sikalidis, C., 1993. Determination of heavy metal uptake by the sodium form of heulandite using radiochemical techniques. Geol. Carpath.-Ser. Clays 44, 115-119.

Mumpton, F.A., 1977. Mineralogy and geology of natural zeolites, Mineralogical Society of America, vol. 4, Virginia Blacksburg.

Mumpton, F.A., 1978. Natural zeolites: A new industrial mineral commodity. In: Sand B.L. \& Mumpton F.A. (eds.), Natural zeolites: Occurrences, Properties, Uses. New York, Pergamon Press, 3-27.

Mumpton, F.A., 1988. Development and uses for natural zeolites: a critical commentary. In: Kallo D. \& Sherry H.S. (Eds.), Occurrence, Properties and Utilization of Natural Zeolites, Budapest, Akademiai Kiado, 333-365.

Papadopoulos, A., Fatta, D., Parperis, K., Mentzis, A., Haralambous, K.J. \& Loizidou, M., 2004. Nickel uptake from a wastewater stream produced in a metal finishing industry by combination of ion-exchange and precipitation methods. Separation and Purification Technology, 39, 181-188.

Pond, G.W. \& Mumpton, F.A., 1984. Zeo-Agriculture: Use of Natural Zeolites in Agriculture and Aquaculture, Colorado, Westview Press, 305pp.

Sikalidis, C.A., 1998. Heavy metals and toxic elements removal from contaminated waters by clay minerals and zeolite bearing rocks. Fourth Int. Conf. on Environmental Pollution, Thessaloniki, Proceedings, 102-110.

Stamatakis, M., Hall, A.\& Hein, R., 1996. The zeolite deposits of Greece. Mineralium Deposita 31,473-481.

Symeopoulos, B., Soupioni, M., Misaelides, P., Godelitsas, A. \& Barbayiannis, N. 1996. Neodymium sorption by clay minerals and zeoliferous rocks. Journal of Radioanalytical and Nuclear Chemistry, Letters, 212, 421-429.

Tserveni-Gousi, A.S., Yannakopoulos, A.L., Katsaounis, N.K., Filippidis, A. \& Kassoli-Fournaraki, A., 1997. Some interior egg characteristics as influenced by addition of Greek clinoptilolitic rock material in the hen diet. Archiv fur Getlugelkunde, 61, 291-296.

Tsirambides, A., 1991. Study of zeoliferous volcaniclastic sediments of Metaxades Evros. Mineral Wealth, 72, 41-48 (in Greek with English summary).

Tsirambides, A., Filippidis, A. \& Kassoli-Fournaraki, A., 1993. Zeolitic alteration of Eocene volcaniclastic sediments at Metaxades, Thrace, Greece. Applied Clay Science, 7, 509-526.

Tsirambides, A., Kassoli-Fournaraki, A., Filippidis, A. \& Soldatos, K., 1989. Preliminary results on clinoptilolite-containing volcaniclastic sediments from Metaxades, NE Greece. Bull. Geol. Soc. Greece, 23, 451-460.

Tsitsishvili, G.V., Andronikashvili, T.G., Kirov, G.N. \& Filizova, L.D., 1992. Natural zeolite. New York, Ellis Horwood, 274pp.

Tsolis-Katagas, P. \& Katagas, C., 1989. Zeolites in pre-caldera pyroclastic rocks of the Santorini volcano, Aegean sea, Greece. Clays and Clay Minerals 37, 497-510.

Tsolis-Katagas, P. \& Katagas, C., 1990. Zeolitic diagenesis of Oligocene pyroclastic rocks of the Metax- 
ades area, Thrace, Greece. Mineralogical Magazine 54, 95-103.

Vlessidis, A.G., Triantafillidis, C.S. \& Evmiridis, N.P., 2001. Removal and recovery of p-phenylenediamines developing coumpounds from photofinishing lab washwater using clinoptilolite tuffs from Greece. Water Research, 35, 1603-1608.

Yannakopoulos, A., Tserveni-Gousi, A., Kassoli-Fournaraki, A., Tsirambides, A., Michailidis, K., Filippidis, A. \& Lutat, U., 2000. Effects of dietary clinoptilolite-rich tuff on the performance of growingfinishing pigs. In: Collela C. \& Mumpton F.A. (Eds.), Natural Zeolites for the Third Millennium, Napoli, De Frede, 471-481. 